\title{
CONGRESS AND THE COMMUNIST MONOLITH: COMMUNIST-FRONT ORGANIZATIONS UNDER THE INTERNAL SECURITY ACT
}

Two recent opinions by the District of Columbia Court of Appeals American Committee for Protection of Foreign Born v. SACB ${ }^{1}$ and Vetcrans of the Abraham Lincoln Brigade v. $S A C B^{2}$ - have relaxed the definitional standards of the Internal Security $\mathrm{Act}^{3}$ as applied to Communist-front organizations, making it easier to bring organizations within the control provisions of the statute and raising serious questions of the act's validity under the first amendment. In both cases the Court of Appeals affirmed findings of the Stbversive Activities Control Board that the two organizations were Communist fronts and were therefore required to register under the act. This registration will result in extensive government control over both the organizations and their members, including submission of membership and financial information, limitation on use of the mails, and effective denial of security clearance to the organization's members. ${ }^{4}$

The Internal Security Act defines a Communist-front organization as any organization in the United States ... which (A) is substantially directed, dominated, or controlled by a Communist-action organization," and $(B)$ is primarily operated for the purpose of giving aid and stipport to a Communist-action organization, a Communist foreign government, or the world Communist movement referred to in section 2 of this title. ${ }^{0}$

1. 331 F.2d 53 (D.C. Cir. 1963), cert. granted, 377 U.S. 915 (1964). The American Committee was organized in 1932 or 1933, and has devoted its major efforts to contestingt naturalization and deportation proceedings. 331 F.2d 54.

2. 332 F.2d 64 (D.C. Cir. 1963), cert. granted, 377 U.S. 989 (1964). The Lincoln Brigade is an organization of veterans who fought in the Brigade during the Spanish Civil War, and has been relatively inactive in recent years. 331 F.2d 66, 71.

3. 64 Stat. 991-93 (1950), 50 U.S.C. $\S \S 783-86$ (1958).

4. Title I of the Internal Security Act, with which this Note is concerned, is entitled the Subversive Activities Control Act and establishes a Subversive Activities Control Board. This Board has the responsibility for determining whether an organization designated by the Attorney General is a Communist-action, Communist-front, or Communistinfiltrated organization. This determination, once final, subjects the organization and its members to the registration and control provisions of the act.

5. A Communist-action organization is

(a) any organization in the United States (other than a diplomatic representative or mission of a foreign government accredited as such by the Department of State) which (i) is substantially directed, dominated, or controlled by the foreign government or foreign organization controlling the world Communist movement referred to in section 2 of this title, and (ii) operates primarily to advance the objectives of such world Communist movement as referred to in said section; and (b) any section, branch, fraction, or cell of any organization defined in subparagraph (a) of this paragraph which has not complied with the registration requirements of this subchapter.

64 Stat. 989 (1950), 50 U.S.C. $\S 782$ (3) (1958).

6. 64 Stat. 989,990 (1950), 50 U.S.C. $\$ 782$ (4) (1958). 
In determining whether an organization falls within the definition's embrace, the Subversive Activities Control Board is directed to "take into consideration" the following factors:

(1) the extent to which persons who are active in its management, direction, or supervision, whether or not holding office therein, are active in the management, direction, or supervision of, or as representatives of, any Communist-action organization, Communist foreign government, or the world Communist movement referred to in section $2 \ldots$ and (2) the extent to which its support, financial or otherwise, is derived from any Communist-action organization, Communist foreign government, or the world Communist movement referred to in section $2 \ldots$ and $(3)$ the extent to which its funds, resources, or personnel are used to further or promote the objectives of any Communist-action organization, Communist foreign government, or the world Communist movement referred to in section $2 \ldots$ and (4) the extent to which the positions taken or advanced by it from time to time on matters of policy do not deviate from those of any Communist-action organization, Communist foreign government, or the world Communist movement referred to in section $2 . .$. T $^{\top}$

The basic problem in the Lincoln Brigade and American Committee cases is the construction and application of the basic statutory definition as amplified by these evidentiary factors.

The initial step in the solution of this problem would seem to be determination of the relationship between the definition and the evidentiary factors. The only insight the statute affords into this relationship is the opaque mandate that the Board consider the four factors. A survey of the legislative history of the act and of the past court decisions interpreting it adds nothing more. ${ }^{8}$ The

7. 64 Stat. 1000 (1950), 50 U.S.C. $\$ 792(f)$ (1958).

8. There was some concern during debate before passage that a finding of substantial presence of just one of the evidentiary factors could satisfy the definition. Indeed, President Truman cited this possibility in vetoing the bill. 96 CoNG. REc. 15630 (1950). But this possibility was rejected by the legislators. Congressman Wood, sponsor of the House bill, said,

I cannot conceive that the Subversive Activities Control Board or any other court would be justified in interpreting and applying these provisions so as to reach such a result.

96 Cong. Rec. 15633 (1950).

If the legislative history establishes conclusively, however, that the presence of one factor alone is not a sufficient basis for determination, it provides few clues as to how much weight the factors should be given - individually or collectively. What discussion there is points toward Congress' provision of the factors merely as guides for the Board and the courts in determining what evidence is relevant - and not exclusive guides at that. Consider Senator Ferguson's remarks:

The positive and governing fact is that the specified eriteria are not absolute nor the ultimate, either individually or even collectively. They are not to be followed slavishly. They simply enumerate the types of evidence which the Board must receive and consider as guides in reaching its ultimate decision.

The ultimate decision will be reached on all the evidence received by the Board....

96 Cong. Rec. 14531 (1950). 
most authoritative judicial discussion of the relationship is by Mr. Justice Frankfurter in Communist Party of the United States v. SACB, where he considered the parallel relationship in the Communist-action provisions of the statute. There he stated only that the Board is required to consider each factor, and to appraise the probative force of the evidence in relation to each factor. ${ }^{10}$ The failure of the courts to articulate a clear relationship between the definition and the evidentiary factors in the Communist-front provisions is more surprising since the first two factors clearly are directed to the control element of the definition and the latter two to the purpose element. ${ }^{11}$

The D.C. Circuit's appreciation of the relationship between the definition and the criteria adds little clarity. For example, in the American Committec case, the court advanced one view of the relationship on the verbal level of the opinion while using quite another approach on the operative level. The court's language implied the necessity for the Board's consideration of all four evidentiary factors in coming to its conclusion on the control element. ${ }^{12}$ Operatively, however, the court concentrated on the first factor. For in considering the control element - whether the organization is "substantially directed, dominated, or controlled by a Communist-action organization" the court turned immediately to the first criterion, and noted that it included not only persons "active in the management, direction, or supervision" of a Communist-action organization, but also representatives thereof. ${ }^{13}$ The entire inquiry into the control element was framed in terms of this factor, and the court's consideration of the other three factors was limited to the flat statement that the Board had considered them and that the record was ample to support the Board's conclusions. ${ }^{14}$ The use of the first factor to focus more precisely consideration of the control element seems appropriate. But the court's concomitant verbal adherence to all four factors is confusing. How, for example, does a finding of substantial presence of the third or fourth factors contribute to a finding of control? Not only does this confusion seem unnecessary, but it also prevents the establishment of a clear relationship between the definition and the evidentiary factors for the future guidance of the Board or a court.

The most difficult problem for the court in the American Committce case was not, however, the control element of the definition, but the purpose element - whether the organization is "primarily operated for the purpose of giving aid and support to a Communist-action organization ...." In its resolt1tion of this problem, the court diluted the standards for imposition of the regulatory provisions.

9. 367 U.S. 1 (1961).

10. Id. at 58.

11. In Lincoln Brigade the court admitted that the first and second factors concerned the control element, the third and fourth factors the purpose element, but insisted on considering all four factors in relation to the entire definition. $331 \mathrm{~F} .2 \mathrm{~d}$ at 71.

12. 331 F.2d at 57.

13. Id. at 56 .

14. Id. at 57 . 
The language of the purpose element seems to require a finding that activities be undertaken with the specific intent to aid and support the Communist movement - that the activities which aid must be done with an intent to aid. Furthermore, that the intent to aid must be the dominant, if not the exclusive, purpose of the organization is indicated by the phrase "primarily operated" in the statutory definition. The significance of the use of the word "primarily" is underscored by the fact that the phrase "substantially directed" is used in the control element of the definition. Despite the juxtaposition of the two words in the same section of the statute and despite the different meanings ordinarily ascribed to these words, ${ }^{10}$ the court began the process of statutory dilution by implying that "primarily" means "substantially."10

With the benefit of this lessening of the government's evidentiary burden, the court proceeded to uphold the Board's finding of the requisite purpose. The court framed its inquiry into purpose primarily in terms of the third evidentiary factor. Factor three directs consideration of

the extent to which its funds, resources, or personnel are used to further or promote the objectives of any Communist-action organization, Communist foreign government, or the world Communist movement referred to in section $2 \ldots .17$

The court construed activities which further Communist objectives to include activities - ordinarily unobjectionable - which in fact aid the party, ${ }^{18}$ since these activities can be a mask behind which Communist power is enhanced. This construction of the third evidentiary factor, in conjunction with a finding of Communist control, was used to impute an intent to aid the party sufficient to satisfy the purpose element of the definition. This reading of the statute is superficially convincing. And the statutory definition when read alone supports the court's construction, since its purpose element seems to require an estimation of the intention with which activities are undertaken rather than an inquiry as to whether the activities considered in themselves - apart from the context of control - might be innocent or even laudable.

15. "Primarily" means "first of all, fundamentally, principally," while "substantial" is defined as "that specified to a large degree or in the main, something of moment, an important or material matter, thing, or part." WeBSTER's THIRD INTERNatroisar Dictionsary (1961). Judge Bazelon, dissenting, also noted the juxtaposition. $331 \mathrm{~F} .2 \mathrm{~d}$ at $61 \mathrm{n.2}$.

16. "The Supreme Court has held that 'primarily' does not necessarily mean principally, it may mean merely substantially." 331 F.2d at 57. The case on which the court relied, Board of Governors v. Agnew, 329 U.S. 441 (1947), concerned a provision of the Banking Act of 1933 prohibiting a partner or employee of a partnership "primarily engaged" in underwriting from being employed by a member bank Under that statute the prohibition was obviously aimed at preventing a conflict of interest, and the possibility of such a conflict was evident in the Agnew case. To imply that the Court's construction of "primarily" in that context - the only time the Supreme Court has construed the word - was controlling here is not persuasive.

17. 64 Stat. 1000 (1950), 50 U.S.C. $\S 792(f)$ (1958).

18. 331 F.2d at 59. 
But the court's construction of the third evidentiary factor distorts the meaning of the word "objectives." There are no grounds for supposing that "objectives," when used to describe the aims of a Communist organization, especially when explicit reference is made to section 2 of the act, is tused in any sense other than that of section 2. Section 2 of the act uses "purposes" and "objectives" interchangeably to refer to the establishment of a "Communist totalitarian dictatorship in the countries throughout the world."10 This use of "objectives" in the sense of an ultimate goal was weakened by the court to use in the sense of a collateral or contributing goal, ${ }^{20}$ thus making a finding of purpose easier to establish.

19. 64 Stat. 987 (1950), 50 U.S.C. $\$ 781$ (1958). Section 2(1) defines the "purpose" of the world Communist movement as the establishment of a "Communist totalitarian dictatorship in the countries throughout the world through the medium of a world-wide Communist organization." 64 Stat. 987 (1950), 50 U.S.C. § 781(1) (1958). "Objectives" for the world Communist movement are not formally defined, but its use in the section indicates that - despite its number - it is interchangeable with "purpose." Indeed, "purpose" is used in its plural form in subsection (5) in the phrase "in furthering the purposes of the world Communist movement." 64 Stat. 988 (1950), 50 U.S.C. \& 781(5) (1958). In the next subsection, the act specifies that Communist-action organizations "carry out the objectives of the world Communist movement" by overthrowing governments and setting up totalitarian dictatorships. 64 Stat. 988 (1950), 50 U.S.C. $\$ 781(6)$ (1958). The means cited indicate clearly that "objectives" means "purpose" as defined. "Objectives of such movement" is used later in the same subsection in what appears to be the same sense. 64 Stat. 988 (1950), 50 U.S.C. \& 781(6) (1958). Subsection (8) uses both "objectives" and "purposes," again without distinction and apparently interchangeably. 64 Stat. 988 (1950), 50 U.S.C. \& 781(8) (1958). Subsection (10) discusses the establishment of totalitarian dictatorships "in pursuance of communism's stated objectives," 64 Stat. 988 (1950), 50 U.S.C. \$ 781(10) (1958), yet the only "stated objective" is the "purpose" definition in subsection (1). The consistent use of the plural could perhaps be a reference to the stated purpose and to the institutional characteristics ascribed to it in subsections (2) and (3). The phrase "stated objectives" is used again in subsection (15) following an implication of particularized restatement of the purpose as the "overthrow of the Government of the United States by force and violence." 64 Stat. 989 (1950), 50 U.S.C. \& 781(15) (1958), Given this usage in section 2, there seems little doubt that "purposes" and "objectives" both refer to the defined "purpose" of the world Communist movement in $\S 2(1)$.

There is no doubt that the restricted reading of the statute advocated here narrowg the gap between a Communist-action and a Communist-front organization. In view of both the severity and the similarity of the controls imposed, discussed infra, this reading does not appear inappropriate.

20. $331 \mathrm{~F} .2 \mathrm{~d}$ at 58,60 .

The effect of this dilution is to uphold a finding of purpose without considering the third factor - properly understood. Yet to do so is to ignore the mandate of Congress to take all factors into consideration. It is true that the Communist Parly case holds that there is no necessity for a finding of substantial presence of all evidentiary factors in the case of a Communist-action organization. Communist Party v. SACB, 367 U.S. 58 (1961). But the statute provides eight rather than four factors for consideration in the case of a Communist-action organization, and the factors held unnecessary seem to be peripheral. There is a distinction, moreover, between not finding a substantial presence of all the factors and not considering a crucial factor correctly. 
The extent of the court's dilution of both the control and purpose elements becomes apparent in the Lincoln Brigade case, where the government's case was based almost exclusively on pre-1950 evidence. The Internal Security Act does not purport to be retroactive in operation, as the court readily admitted.21 The definition of a Communist-front organization as well as the rest of the statute is cast in the present tense; and, as the court pointed out, in view of the different policy attitudes of the United States toward the Soviet Union in the 1930's, '40's, and '50's, the date of the evidence was of crucial importance. To the reasons given by the court may be added the reason that the act in both title and concept is a control device, designed to prevent by exposure and sanction the accomplishment of defined Communist aims in this country; $; 3$ it was not designed to exhume skeletons and condemn them to perpetual infamy.21 Although the Communist Party case held that a court may legitimately rely on institutional history to establish a context for determination of current control and purpose, ${ }^{25}$ not even that case went so far as to hold that the pre-act history is determinative of an organization's present status.

Despite its recognition of the importance of the date of the evidence, the court in Lincoln Brigade allowed consideration of pre-1950 evidence on the grounds that current activities may be viewed "in the context of, or through the coloration of, the past." 28 The extent of this shading becomes apparent on closer examination. The court's discussion of control was explicitly phrased in terms of the first evidentiary factor - whether persons active in the control of the organization are officers, representatives, or functionaries of the party. In determining control, the Board found that the Brigade had operated for the past five years into the present through two principal active officers and that these officers were party functionaries. ${ }^{27}$ But the court overruled this finding. ${ }^{28}$ The court, however, did uphold the Board's finding that four of the nine members of the Brigade's National Committee were party functionaries. 20 Yet 1949 was the date of the latest evidence concerning any of them: Weisman was said to be a party organizer at that time; Nelson's status was established

21. "This statute is cast in the present tense .... It is designed to compel the public registration of organizations which, subsequent to the passage of the Act, operate to aid the aims of the Communist movement." Lincoln Brigade v. SACB, 331 F.2d 64, 67-68 (1963).

22. Id. at 68.

23. See particularly 64 Stat. $989,992-97$ (1950), 50 U.S.C. $\$ \S 781$ (15), 784-90 (1958). Title I of the act is titled "The Subversive Activities Control Act."

24. See, e.g., 64 Stat. 998 (1950), 50 U.S.C. \& 792 (1958), providing for cancellation of registration of an organization or individual.

25. 367 U.S. 1,69 (1961).

26. 331 F.2d at 72 .

27. Id. at 71 .

28. Id. at $70-71$.

29. Id. at 71. This finding reduced to four the number of party functionaries among the eleven top officers of the Brigade. The Board had found eight to be functionaries, including the two principal officers. Id. at 70 . 
by evidence dating from 1946; Love's status by his activities in Spain in 1938; and Smith's status by his continued loyalty to Earl Browder after the latter was expelled from the party in $1946 . .^{30}$ Even assuming the general relevance of pre-act evidence, the staleness of this particular evidence greatly weakens its probative force.

Having found that four members of the National Committee were party functionaries, the court inferred their participation in management of the Brigade from their membership on the National Committee upon the assumption - unsupported by evidence - that it was reasonable to assume a small National Committee had duties relating to management. ${ }^{31}$ Perhaps recognizing the tenuous nature of the foregoing evidence, the court stopped short of concluding that the control element had been satisfied. Rather it buoyed its position by asserting record support for the other three evidentiary factors, for the "Board must take into consideration all four of these specifications in determining the applicability of the whole of the statutory definition." ${ }^{32}$ Not only did the court not explain how consideration of the other factors helped establish control by the party, but it also failed to reconcile this position with its earlier identification between the control element and the first factor.

Even assuming that consideration of the other three factors was relevant in determining control, most of that evidence, as the court acknowledged, concerned pre-1950 activities. ${ }^{33}$ Nor did the Brigade's activities since passage of the act appear particularly ominous. ${ }^{34}$ The only damning evidence since passage of the act to which the court referred concerned the "non-deviation" evidentiary factor - whether the Brigade's policy positions deviated from those of the party. Surprisingly, no reference to the purpose element of the definition was made during this non-deviation discussion. Yet at the conclusion of this discussion the court, which had been unable to uphold a finding of control on the basis of Brigade leadership, abruptly and without further explanation approved the Board's findings of both the control and the purpose clements..$^{35}$

30. $I d$. at 70 .

31. How "reasonable" this inference and this assumption were may be viewed in the light of the absence of evidence that the two principal officers were party functionaricg, the evidence that a minority of the National Committee were functionaries, and in the contention of the Brigade - contradicted only by one letter of April 25, 1952, signed by the entire National Committee - that the executive board had not functioned since 1949. Id. at 70.

32. Id. at 71 .

33. Id. at 70 .

34. The Brigade says in its brief to us that since ... [passage of the Act] its activities have consisted of social affairs, statements in opposition to the Franco regime, the rehabilitation of Brigade members in need of aid, support of its members indicted under the Smith Act, particularly Nelson and Weissman, and defense of itself in the present proceeding. The report of the Board does not materially contradict this factual position.

Id. at 71 .

35. Id. at 72-73. 
The court's focus on the non-deviation evidence may be criticized not only for its failure to demonstrate Communist control of the Brigade either in the pre-1950 or post-1950 years, but also because it, in effect, reduced the purpose element of the definition to a less than convincing demonstration of nondeviation. Non-deviation standing alone seems to have little probative force on the issue of purpose; opposition to the Internal Security Act, for example, is hardly proof of an intent to aid the party, and the same may be said of other lawful causes, which may be shared with the party only by coincidence. ${ }^{30}$ Moreover, by allowing the purpose element of the statutory definition to be satisfied by a mere showing of non-deviation, the court in Lincoln Brigade sacrificed the last mooring that the American Committee case had in the statutory definition - the inference of a purpose to aid the party drawn, in part, from a clear finding of control. Amid the confusion resulting from its failure to establish a clear relationship between the elements of the definition and the evidentiary factors, the court ironically affirmed a finding of both control and purpose when the evidence relevant to each element alone was insufficient to establish its existence.

In sum, the court's construction of the act in the Lincoln Brigade and American Committee cases broadened the statutory provisions in two ways: by the inclusion of collateral as well as ultimate objectives of the party within the word "objectives" in the third evidentiary factor, thereby allowing proscription of an organization which in no way attempted direct advancement of those ultimate objectives; and by the satisfaction of the purpose element by merely finding, in effect, non-deviation, thereby undercutting the requirement of an intent on the part of the organization to aid the party.

This broadening of the statute extends the reach of the act into the area of protected first amendment freedoms and raises serious constitutional questions. $^{37}$ The first such question stems from De Jonge 2. Oregon ${ }^{38}$ and Scales v. United States. ${ }^{39}$ These cases establish the proposition that activities within the ambit of the first amendment may not be curtailed by criminal sanctions when the activities themselves are lawful. In $D c$ Jonge (a criminal syndicalism prosecution under Oregon law) the Supreme Court held that the first amendment prohibited punishment of a Communist Party member for participation in a lawful meeting. First amendment protection was accorded even though the organization itself engaged in unlawful activity. ${ }^{40}$ The Court reaffirmed this policy in Scales, even though upholding a Smith Act conviction, by requiring

36. The satisfaction of the purpose element in both the American Commillec and Lincoln Brigade cases, then, relies heavily upon the non-deviation faclor. And this reliance illustrates a role for that factor closely akin to that envisioned by then-Representative Nixon in debate prior to passage: "[I]f this particular standard is striclien out, it would be virtually impossible in many cases to get sufficient evidence before the Subversive Activities Control Board to justify a finding that an organization was a Communist front." 96 CoNG. REC. 13764 (1950).

37. This is the position taken by Judge Bazelon in dissent.

38. 299 U.S. 353 (1937).

39. 367 U.S. 203 (1961).

40. 299 U.S. 353, 359-60, 365 (1937). 
proof not only of membership in the party which engaged in illegal activity, but also of intent to advance its illegal objectives.11

Of course, the laws involved in De Jonge and Scales involved criminal sanctions. And it might be argued that the Communist Party case, which upheld the constitutionality of the registration provisions as applied to Communistaction organizations, implied a refusal to extend the rationale of $D c$ Jongc and Scales since the Internal Security Act did not itself make the party's acu tivity illegal and since only civil regulations were imposed. ${ }^{42}$ If this were all, the statutory provisions applied to the American Committee and the Lincoin Brigade would appear constitutional under the same rationale, since the Communist-front provisions also apply civil rather than criminal sanctions. But it cannot be inferred from the failure of the court in the Communist Party case to find specifically that the party was engaged in criminal activity, that the Court viewed the activities of the party as legal. The finding of protracted organizational activity under foreign domination having as its objective the establishment of a totalitarian dictatorship was tantamount to a finding of conduct made criminal by the Smith Act. ${ }^{3}$ If illegal activity be attributed to the party, then the Communist Party case seems clearly outside the rule suga gested by De Jonge and Scales - that innocent activity or innocent participation in illegal activity are protected by the first amendment.

The American Committee and Lincoln Brigade cases, unlike the Commumist Party case, involve activities not prohibited by the Smith Act or any other statutes. And since the Communist Party case apparently did not decide that De Jonge and Scales are inapplicable when civil sanctions are used to curtail lawful activities, that question remains open. The consequences of registration under the Internal Security Act, moreover, are sufficiently severe to diminish the conceptual gap between those "civil" sanctions and more traditional criminal sanctions. The sanctions, for example, imposed on members of Communistfront organizations ${ }^{44}$ include effective denial of secturity clearance, ${ }^{45}$ deninl of

41. If there were a similar blanket prohibition of association with a group having both legal and illegal aims [as contrasted with a criminal conspiracy], there would indeed be a real danger that legitimate political expression or association would be impaired ... [T] The member for whom the organization is a vehicle for the advancement of legitimate aims and policies does not fall within the ban of the statute....

367 U.S. at 229.

42. Criminal penalties are imposed, however, for failure to register. 64 Stat. 1002 (1950), 50 U.S.C. $\$ 794$ (1958).

43. 54 Stat. 671 (1940), 18 U.S.C. $\$ 2385$ (1958).

44. The registration provisions themselves require that organizations determincd to be Communist fronts submit annual registration statements containing 1) the name of the organization and the address of its principal office, 2) the name, allas, adtress, title, and duties of current officers or officers who have served within the preceding twelve months, and 3) an accounting, in accordance with regulations promulgated by the Attorney General, of money received and the sources thereof and money expended and the purposes therefor. 64 Stat. 994 (1950), U.S.C. $\$ 786$ (b), (d) (1958).

45. 64 Stat. 991 (1950), 50 U.S.C. $\$ 783$ (b) (1958). 
government employment, ${ }^{46}$ effective denial of defense industry employment, ${ }^{47}$ and denial of passport. ${ }^{48}$ In the light of the lawfulness of the activities of the American Committee and the Lincoln Brigade and of the severity of the sanctions imposed upon the organizations and their members, the argument for the inapplicability of De Jonge and Scales on the grounds of a distinction between civil and criminal sanctions is not persuasive. Once this possible constitutional infirmity of the Communist-front provisions is recognized, it would seem that a courc ic obligated to construe the act narrowly, thereby leading to a reversal of the Boarc's registration order, in order to avoid this constitutional issue.49

Even if the rationale of $D e$ Jonge and Scales were found inapplicable to the cases at hand, it is clear, as the Commmunist Party' case admitted, to that the "chilling effect" of the registration requirements upon the exercise of first amendment rights is sufficient to require a balancing of this imposition against the "magnitude of the public interests which the registration and disclosure provisions are designed to protect." 51 The Community Party court framed this balance in terms of "the impediments which particular governmental regulation causes to entire freedom of individual action" and "the value to the public of the ends which the regulation may achieve."'62 The Commumist Party case found that the public interest justified imposition of the registration controls against Communist-action organizations. But it carefully and specifically confined its holding to the case of foreign-dominated organizations with objectives of overthrowing the government and establishing a totalitarian regine. This careful limitation seems to make its own argument against automatic extension of the Communist Party case adjudication of constitutionality to the instant cases, in which the organizations were not shown to have either direct foreign domination or the ultimate objectives of the Communist Party. It is doubtful, then, whether application of the balancing test would result in justification of the control provisions, and this possibility presents another compelling reason for construing the statute narrowly so as to avoid the constitutional question.

Aside from these two constitutional issues, there are other considerations which should impel a court to construe the Internal Security Act restrictively. The act is unusual in that it is explicitly based upon extensive congressional findings of "fact" concerning the nature of the world Communist movement

46. 64 Stat. 992 (1950), 50 U.S.C. $\$ 784$ (a) (1)(B) (1958).

47. 64 Stat. 992 (1950), 50 U.S.C. § 784(a) (1) (C) (1958).

48. 64 Stat. 993 (1950), 50 U.S.C. $\S 785$ (1958). This provision, $\S 6$ of the act, was declared unconstitutional by the Supreme Court on first amendment grounds in Aptheler v. Secretary of State, 378 U.S. 500 (1964).

49. For expressions of this widely accepted canon of statutory construction, sce United States v. Rumely, 345 U.S. 41, 45 (1953); Crowell v. Benson, 285 U.S. 22, 62 (1932) ; Lucas v. Alexander, 279 U.S. 573, 577 (1929); Richmond Screv Anchor Co. v. United States, 275 U.S. 331, 346 (1928).

50. 367 U.S. 1, 91 (1961).

51. Ibid.

52. Ibid. 
and the danger of that movement to the internal security of the United States.ta These findings were made as a result of a decade's investigation by the House Committee on Un-American Activities. ${ }^{54}$ The reasons for the inclusion of these findings in the act are not explicitly stated, but it seems reasonable to ascribe at least two purposes to Congress: to ensure the act's constitutionality by spelling out the dangers motivating passage of the act, and to provide a controlling legislative history setting forth explicitly the intent with which Congress passed the act.

But the "facts" found by Congress in 1950 are necessarily tied to the conditions and circumstances under which they were found. Their accuracy, and even their relevance, in future years is limited by the degree to which the conditions under which they were found remain unchanged. The act was passed in 1950, immediately after the outbreak of the Korean war and amid the rising tide of McCarthyism. To read the act is to sense the mood of Congress :

The Communist movement in the United States is an organization numbering thousands of adherents, rigidly and ruthlessly disciplined. Awaiting and seeking to advance a moment when the United States may be so far extended by foreign engagements, so far divided in counsel, or so far in industrial or financial straits, that overthrow of the Government of the United States by force and violence may seem possible of achievement, it seeks converts far and wide by an extensive system of schooling and indoctrination. Such preparations by Communist organizations in other countries have aided in supplanting existing governments. The Communist organization in the United States, pursuing its stated objectives, the recent successes of Communist methods in other countries, and the nature and control of the world Communist movement itself, present a clear and present danger to the security of the United States and to the existence of free American institutions . . . .65

In this passage, Congress set forth three factors which together constitute a clear and present danger to United States security and which designate conditions motivating passage of the act: 1) a strong Communist organization within this country intent on overthrowing the government and establishing a totalitarian dictatorship; 2) recent successes by similar organizations in other countries; 3) a monolithic, highly disciplined, worldwide movement. ${ }^{\text {to }}$

In 1965, however, the truth of these bases of the statute is no longer evident. While the effective strength of the Communist Party in this country is diffcult to determine accurately, in 1961 party membership was estimated at 10,000 , half the party strength in 1956.57 It is at least doubtful that the Com-

53. 64 Stat. $987-89$ (1950), 50 U.S.C. \$ 781 (1958).

54. 2 U.S. Code Cong. Service 3886 (1950).

55. 64 Stat. 989 (1950), 50 U.S.C. \$ 781(15) (1958).

56. The addition of detail in this denotation is drawn from the subsections of the act immediately preceding the quoted passage. See note 53 supra.

57. Avakumovic, World Communism in Figttres, 17 INT'L J. 151, 152 (1962). Party membership was 20,000 in $1956,7,000$ in 1957 , and 10,000 in 1961 . No estimates are cluoted for the Communist Party of the United States of America for 1939 and 1947. 
munist Party in the United States in the 1960's is as strong as it was at the time of passage of the act. Indeed, its strength has probably lessened. ${ }^{\text {os }}$ Since the passage of the act, moreover, there has been no takeover by Communists of industrialized countries comparable to the fall of Eastern Europe in the years immediately following World War II and immediately preceding the passage of the act. Similarly, events of the last decade and a half have clearly shattered the notion that the world Communist movement is a monolith. ${ }^{69}$ The denth of Stalin in 1953 and the emergence of Communist China as a major power have triggered a fragmentation of the Communist movement, which is continuing, perhaps at an accelerated pace, today. ${ }^{60}$ In President Johnson's words, "In [the last four years] . . no new nation has become Communist, and the

58. One helpful index of the degree of national concern about the party is the volume of periodical literature concerning it; that volume has declined markedly in the last 15 years. See, e.g., the material indexed in Public Affairs Inforaration Service and Render's Gutde to Periodical Literature over this period.

59. The change has been well stated by Wolfgang Leonhard:

For almost a quarter century, from 1929 until 1953, international communism was characterized first and foremost by monolithic unity. All the Communist partics of the world (with the exception, since 1948, of the Yugoslav one) were subordinated to Stalin's leadership in Moscow. Every political shift of the Kremlin was obeyed by Communist parties from Germany to Indonesia. One nod from Mroscow was all that was needed to remove a displeasing leader and to appoint a desirable one; one phrase in a Soviet article was enough to alter overnight the line of any party. The uniform monotony went so far that Communist Party resolutions in Sweden, Ceylon or Venezuela could hardly be distinguished one from the other. To be sure, during this period there existed, probably more than has been generally assumed until now, serious opposition to Soviet domination, criticism of the line handed down from Mroscow, oppositionist currents and different concepts and controversies, but these could not be aired openly in the conditions prevailing at that time. In that quarter century the international Communist movement seemed not only to the outside world, but even to many of its own members - like an instrument uniformly directed and led from Mloscow, without any independence whatsoever.

All this now belongs to the past. Within a few years the Communist world movement has departed from its earlier monolithic structure to an astonishing extent and with startling swiftness. This development has led to the formation within the international Communist movement of several political groupings which take entirely different attitudes toward decisive political questions; it has led to open controversies between these different groupings and, consequently to new relations within the movement as a whole.

Leonhard, $A$ World Irz Disarray, 13 Problems of Coscrumisar 16 (1964). See generally Dalitn, Diversity in International Coararunisar (1963); Laquer and Laddez, Polycentrism: The New Factor in Internatronal Comarumisar (1962); 12 Progleass of Commonsisar (1963) ; Lowenthal, Communists of the World UniteP N.Y. Times, Oct. 25, 1964, \& 6 (Magazine), p. 24.

60. The Polish and Italian parties have taken the lead in arguing for more genuine equality and autonomy among the parties, and their position has been formally recognized in Communist documents since 1957. Dallis, op. cit. supra note 59 at xxix. And in 1960 the Soviet Communist Party indicated that it did not wish to be designated as the leading Communist Party. Ibid. 
unity of the Communist empire has begun to crumble."01 One result of this fragmentation has been a relaxation of internal discipline and a dispersion of control and authority within the international Communist structure. These developments imply that the integrity of the worldwide movement's power base is disintegrating, with a consequent weakening of both control of and support for the internal Communist Party by the international movement. The coupling of these developments with the decline in internal party numerical strength has undermined the congressional findings upon which the Internal Security Act was based.

If the act's findings of fact be viewed as an exposition of the magnitude of the public interest which constitutionally justifies the imposition of controls, the questionable validity of those facts today may alter the constitutional balance. To avoid making the constitutional decision under these changed circumtances, the court should construe the act narrowly.

But the changed conditions since the congressional findings of fact have broader implications than the casting of doubt upon the act's constitutional justification. For the continued validity of these findings of fact is crucial to application of the act in accord with congressional purpose. That purpose is to preserve and protect the "security of the United States" and the "existence of free American institutions" from the "clear and present danger" of subversion by the internal Communist movement, one tentacle of an octopus-like world movement tightly controlled by a foreign government. To the extent that this danger has diminished, congressional purpose is satisfied. The broad application of the act in the face of doubtful contemporary validity of the findings of fact justifying its passage may be a distortion rather than a fulfillment of congressional purpose. ${ }^{2}$ To avoid guessing about congressional

61. 111 Cong. Rec. 27 (1965) (State of Union Message).

62. Block v. Hirsch, 256 U.S. 135 (1921), and Chastleton Corp. v. Sinclair, 264 U.S. 543 (1924), concerned the District of Columbia Rent Act, which established tenant and rate controls within the District of Columbia. This act was originally passed and justificd by Congress as a war emergency measure in 1919. Its life was extended in 1922 for two more years. The Court, speaking through Mr. Justice Holmes, upheld the act in the Hirsh case, though noting that factual determination by Congress of an emergency was not conclusive. In Chastleton, the Court remanded for determination of factual justification as of the times in question. The Court, again speaking through Mr. Justice Holmed, said that while respect was due the legislature's determination of fact, the Court was not at liberty to shut its eyes to a legislative mischaracterization as of the time of passage; and as to future times, "A law depending upon the existence of an emergency or other certain state of facts to uphold it may cease to operate if the emergency ceases or the facts change even though valid when passed." 264 U.S. 543, 547-48 (1924).

Nor is the Commumist Party case to the contrary. Though the opinion is murky on this point, it does not preclude consideration of the argument just made. It is true that the Court stated that the congressional findings of fact were "not open to re-examination by the Board." 367 U.S. 1, 112 (1961). While this would seem to bind the Board perpetually to what was the case in 1950, Mr. Justice Frankfurter volatilized the "facts" into "defining terms whose truth, as such, is irrelevant to the issues in such procecdings." Ibid. Thus the finding of $\S 2$ enumerates the characteristics of the "world Communist 
intent in the light of changed conditions, the court should steer the conservative course of narrow construction of the statute. This conservative course, moreover, would uphold the values of a democratic society by preventing, in the absence of clear congressional design, indiscriminate application of harsh civil sanctions and the attendant infringement of the right of free speech and association. This is not to suggest that the court substitute its judgment for that of Congress by insisting that the congressional findings be re-examined in every prosecution. Nor is it to suggest that the court abrogate the act by refusing to enforce it on grounds of changed conditions. It is to suggest merely that substantial change from the context in which its findings were made, change casting serious doubt upon their continued validity, dictates a strict reading of the statutory provisions.

The doubtful validity today of the facts upon which the act is based and the questionable constitutionality of its broad construction reinforce the conclusions drawn from a close reading of the statute. These conclusions indicate that a broad application of the act - the reading of "objectives" in the third evidentiary factor to mean objectives of an organization collaterally to aid the Communist Party and the satisfaction of the purpose element of the definition by a tenuous showing of control by the party and a substantial degree of non-deviation from the policy positions of the party - is a misconstruction of the act. And in both the American Committee and Lincoln Brigade cases this misconstruction has resulted in affirmance of a Board registration order against organizations whose activities were admittedly lawful and whose purposes to aid the Communist Party were not clearly demonstrated.

movement" as that movement existed in 1950. The board or a reviewing court, then, is able to say, as a matter of "statutory interpretation," that "the "world Communist movement, as Congress meant the term in 1950 ... no longer exists, or that Country X or Y, not the Soviet Union, now directs it." Id. at 113. The determinations advocated here that the world movement is no longer a monolith, and that the internal party has declined in strength - are similar to the examples used by the court justifying "statutory construction." The Communist Party case, therefore, offers no authority for the contention that a court is irrevocably tied to the congressional findings of fact rooted in the 1950 context. 